\title{
Pengaruh Earning Per Share (EPS) Dan Return On Equity (ROE) Terhadap Harga Saham \\ (Studi Kasus pada Bank BUMN yang Terdaftar di Bursa Efek Indonesia Periode 2017 - 2019)
}

\section{Asih Handayani}

\author{
1) Universitas Pamulang, email : asih.handayani52@gmail.com
}

\section{ARTICLES INFORMATION}

\section{ABSTRACT}

\section{JURNAL SEKURITAS \\ (Saham, Ekonomi, Keuangan dan Investasi ) \\ Vol.4, No.2, Januari 2021 Halaman : $169-179$ \\ (C) LPPM \& Prodi Manajemen UNVERSITAS PAMULANG \\ ISSN (online) : 2581-2777 ISSN (print) : : 2581-2696}

\section{Keyword :}

Earning per Share; Return on Equity; Harga Saham

$J$ E L. classification:

C 33, G 21, G 24, N 15, N 25

\section{Contact Author : \\ PRODI MANAJEMEN UNPAM \\ JL.Surya Kencana No.1 \\ Pamulang Tangerang Selatan - Banten \\ Telp. (021) 7412566, Fax (021) 7412491 Email : \\ sekuritas@unpam.ac.id}

Penelitian ini bertujuan menganalisa dampak EPS serta ROE terhadap Harga Saham perusahaan publik khususnya Bank BUMN. Seberapa besar harga saham dipengaruhi oleh EPS dan ROE secara parsial dan simultan. Data penelitian diambil dari BEI. Sampel ditentukan berdasarkan kriteria tertentu atau purposive sampling. Metode penelitian menggunakan deskriptif kuantitatif dan pengujian data dilakukan menggunakan Eviews 9. Persamaan yang didapat hasil dari regresi linear berganda adalah $Y=557,6227+$ $0,908954 X_{1}-20,12882 X_{2}$ dengan probabilitas EPS 0,0000 dan ROE 0,6617. Berdasarkan hasil pengujian tersebut dan signifikansi 0,05 maka dapat disimpulkan bahwa EPS memiliki pengaruh terhadap harga saham dan ROE memiliki pengaruh yang lemah terhadap harga saham secara parsial. Kedua variabel bebas, yaitu EPS dan ROE secara bersama-sama memiliki pengaruh terhadap harga saham.

This study aims to analyze the impact of EPS and ROE on stock prices of public companies, especially state-owned banks. How much share price is influenced by EPS and ROE partially and simultaneously. Research data is taken from the IDX. The sample is determined based on certain criteria or purposive sampling. The research method used quantitative descriptive and data testing was carried out using Eviews 9. The equation obtained from multiple linear regression is $Y=557.6227+$ 0.908954 X1 - 20.12882 X2 with a probability of EPS 0.0000 and ROE 0.6617. Based on the test results and the significance of 0.05, it can be concluded that EPS has an influence on stock prices and ROE has a weak effect on stock prices partially. The two independent variables, namely EPS and ROE together have an influence on stock prices. 


\section{A. PENDAHULUAN}

Pasar modal merupakan lembaga yang menyediakan sarana bagi investor dan perusahaan untuk saling bertransaksi tanpa harus bertatap muka. Bagi perusahaan, menjadi perusahaan publik dengan melakukan initial public offering (IPO) merupakan kesempatan emas untuk melakukan ekspansi tanpa mengeluarkan modal sendiri dengan meraih kepercayaan dari investor masyarakat yang berinvestasi di pasar modal. Investor sendiri mendapatkan keuntungan dengan adanya pasar modal, dimana siapa saja bisa menjadi investor sekalipun dengan modal yang relatif kecil. Harga saham yang fluktuatif membuat para investor banyak yang memainkan saham secara trading, dimana ketika harga saham turun segera membeli dan menjualnya pada saat harga saham naik.

Harga saham sendiri bisa diprediksi dengan cara menganalisa laporan keuangan historis perusahaan. Analisa laporan keuangan digunakan untuk lebih memahami informasi terkait dengan kondisi keuangan perusahaan serta mencerminkan kemampuan perusahaan bertahan dalam persaingan pasar. Selain itu, analisa laporan keuangan dapat dijadikan early warning system apabila pada suatu waktu terjadi ketidakberesan atau indikasi kebangkrutan perusahaan.

Instrumen yang sering digunakan sebagai alat analisa laporan keuangan adalah earning per share (EPS) dan return on equity (ROE). EPS merupakan rasio yang dipakai untuk melihat kondisi perolehan keuntungan perusahaan terhadap keseluruhan jumlah saham yang beredar, sedangkan ROE sendiri merupakan rasio yang dipakai untuk melihat seberapa mampu entitas menghasilkan laba.

Dalam pasar modal, terdapat banyak sektor industri salah satunya adalah industri perbankan. Saham-saham Bank termasuk yang paling banyak diminati oleh investor dikarenakan banyaknya investor yang percaya bahwa pasar uang merupakan industri yang menjanjikan karena pasar uang yang cenderung berkembang pesat setiap tahunnya. Saat ini, harga saham termahal rekornya masih dipegang oleh industri perbankan yaitu saham BBCA milik PT Bank Central Asia Tbk.

Berdasarkan pendahuluan di atas, penulis tertarik untuk mendalami dan menganalisa lebih lanjut terkait dengan saham perbankan dan mengambil judul penelitian "Pengaruh EPS dan ROE terhadap Harga Saham (Studi Kasus pada Bank BUMN yang Terdaftar di Bursa Efek Indonesia Periode 2017 - 2019)."

\section{B. RUMUSAN MASALAH}

Uraian pendahuluan di atas menghasilkan perumusan masalah berikut ini:

1. Bagaimanakah signifikansi pengaruh antara EPS dengan harga saham pada tahun $2017-2019 ?$

2. Bagaimanakah signifikansi pengaruh antara ROE dengan harga saham pada tahun $2017-2019 ?$

3. Bagaimanakah signifikansi pengaruh secara simultan antara EPS dan ROE dengan harga saham pada tahun $2017-2019 ?$ 


\section{TUJUAN PENELITIAN}

Uraian pendahuluan dan perumusan masalah di atas memiliki tujuan berikut ini:

1. Untuk menilai signifikansi pengaruh antara EPS dengan harga saham pada tahun $2017-2019$

2. Untuk menilai signifikansi pengaruh antara ROE dengan harga saham pada tahun $2017-2019$

3. Untuk menilai signifikansi pengaruh antara EPS dan ROE dengan harga saham secara bersama-sama pada tahun 2017 - 2019

\section{KERANGKA BERPIKIR}

\section{Gambar 1.1 \\ Kerangka Berpikir}

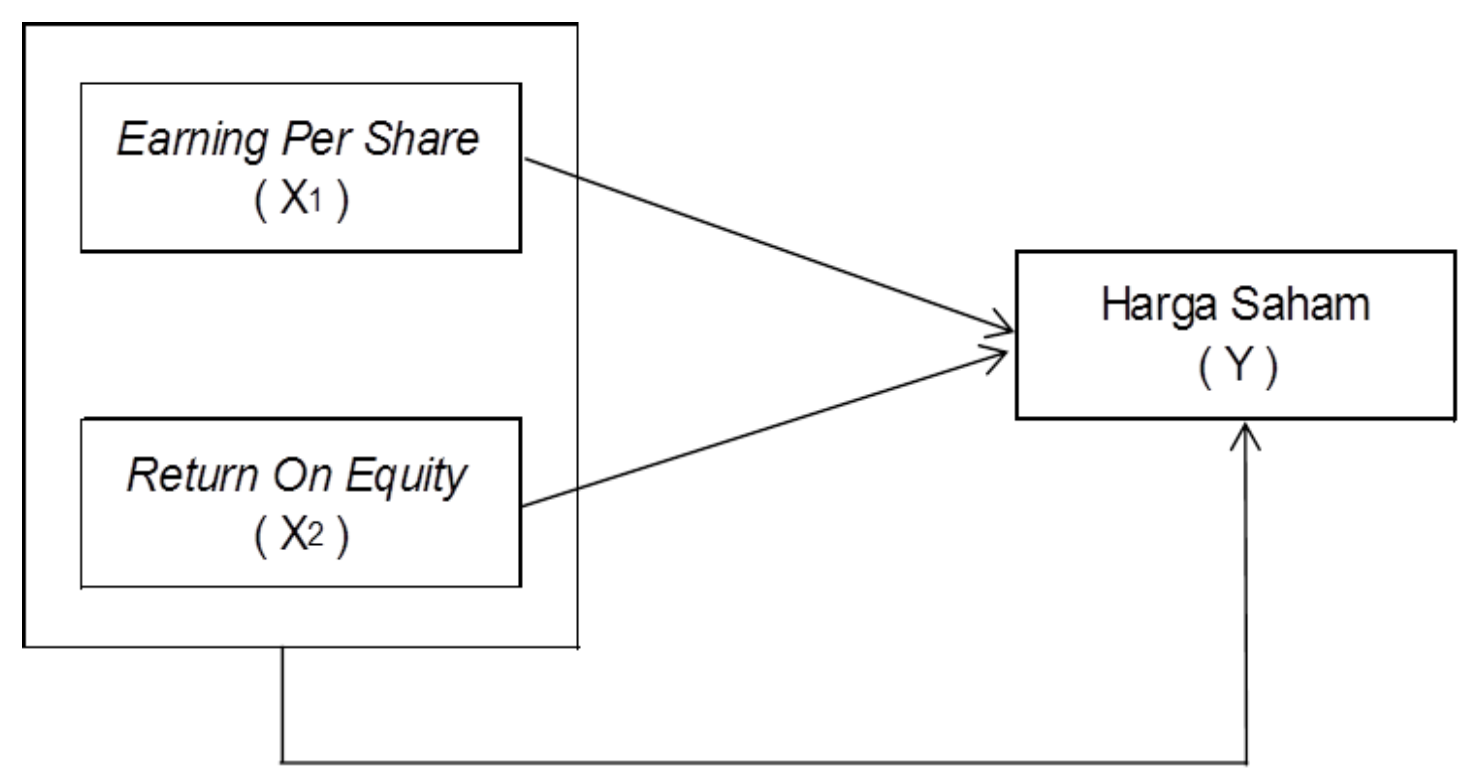

\section{E. HIPOTESIS}

Perusahaan publik secara umum memiliki orientasi menghasilkan keuntungan sebesarbesarnya dengan cara meningkatkan kinerja keuangannya setiap tahun. Hal tersebut merupakan tanggung jawab dan tuntutan yang harus dipenuhi perusahaan publik atas kepercayaan yang diberikan investor sebagai pemegang saham perusahaan.

Keuntungan yang dihasilkan perusahaan per lembar saham atau EPS berpengaruh terhadap keinginan investor membeli lebih banyak lagi saham perusahaan tersebut atau bahkan melepaskan investasinya. Semakin tinggi nilai EPS maka semakin tinggi pula keinginan investor untuk membeli saham perusahaan dan mengakibatkan naiknya harga saham perusahaan. Berdasarkan penjelasan tersebut di atas, maka hipotesis yang diambil oleh penulis adalah sebagai berikut:

\section{$H_{1}$ : Terdapat pengaruh signifikan secara parsial antara EPS terhadap harga saham periode $2017-2019$}

Investor tidak hanya melihat seberapa besar kemampuan perusahaan menghasilkan laba, tapi juga melihat dari sisi seberapa besar kemampuan perusahaan mengelola Jurnal SEKURITAS (Saham, Ekonomi, Keuangan dan Investasi ), Vol.4, No.2 , Januari 2021 ....171 
ekuitasnya untuk menghasilkan keuntungan. Penilaian investor terhadap perusahaan yang memiliki tingkat ROE tinggi dianggap mampu mempertahankan kelangsungan hidup perusahaan bahkan dalam kondisi krisis sekalipun.

Semakin tinggi tingkat ROE perusahaan maka semakin tinggi pula permintaan investor terhadap saham perusahaan tersebut yang menimbulkan kenaikan harga saham perusahaan pada pasar modal. Hal ini menghasilkan hipotesis sebagai berikut:

\section{$\mathrm{H}_{2}$ : Terdapat pengaruh signifikan secara parsial antara ROE terhadap harga saham periode $2017-2019$}

\section{$\mathrm{H}_{3} \quad$ : Terdapat pengaruh signifikan secara simultan antara EPS dan ROE terhadap harga saham periode $2017-2019$}

\section{F. KAJIAN LITERATUR}

\section{Pasar Modal}

Undang-Undang No. 8 Tahun 1995 tentang Pasar Modal, "pasar modal ialah kegiatan terkait penawaran umum, perdagangan efek dan perusahaan publik yang menerbitkan efek, serta lembaga dan profesi yang berkaitan dengan efek yang dipedagangkan tersebut. Bursa efek dikenal sebagai lembaga yang menyediakan sistem dan/atau sarana untuk jual beli efek di pasar modal."

\section{Saham}

Menurut Sjahrial (2012:19), "Saham merupakan surat berharga yang berasal dari perusahaan berbentuk perseroan terbatas yang melakukan penawaran umum (Initial Public Offering/IPO). Perseroan terbatas yang telah berhasil IPO disebut sebagai emiten dan masyarakat yang membeli saham emiten pada saat IPO dinyatakan sebagai pemilik sebagian perusahaan atau sering disebut dengan pemegang saham perusahaan atas lembar saham yang dibelinya."

\section{Harga Saham}

Menurut Sunariyah (2011: 13), "penawaran dan permintaan saham emiten mempengaruhi tinggi rendahnya harga saham tersebut. Selain itu, hal lainnya yang mempengaruhi harga saham adalah kebijakan internal perusahaan beserta kinerja yang dicapainya. Harga saham juga dapat dipengaruhi oleh kondisi-kondisi di luar perusahaan seperti: gejolak politik, kebijakan moneter, inflasi, dan lain sebagainya".

\section{Earning per Share (EPS)}

Menurut Oktavian (2019:160), "EPS diartikan sebagai laba dari setiap lembar saham perusahaan. Rasio ini menunjukkan seberapa tinggi tingkat perolehan laba perusahaan. Hal ini yang menarik investor untuk membeli saham perusahaan dengan tujuan mendapatkan keuntungan sebesar-besarnya." Berikut ini EPS jika dinyatakan menggunakan rumus:

$$
\text { EPS }=\frac{\text { Laba Bersih }}{\text { Setelah Pajak }}
$$




\section{Return on Equity (ROE)}

Menurut Prihadi (2012: 261), "bagi pemegang saham, rasio ini merupakan rasio profitabilitas yang paling penting dimana ROE dianggap mampu mengukur seberapa perusahaan menghasilkan laba dari modal pemegang saham yang ada." ROE dapat dihitung dengan membagi laba bersih setelah pajak dengan total ekuitas, berikut jika ditulis menggunakan rumus:

$$
\text { ROE }=\frac{\begin{array}{c}
\text { Laba Bersih } \\
\text { Setelah Pajak }
\end{array}}{\text { Total Ekuitas }}
$$

\section{G. METODOLOGI PENELITIAN}

\section{Jenis dan Pendekatan Penelitian}

Penelitian ini merupakan penelitian jenis deskriptif kuantitatif dengan pendekatan asosiatif. Dimana, penelitian ini memiliki tujuan untuk mengetahui signifikansi pengaruh antara dua variabel atau lebih. Metode penelitian deskriptif kuantitatif merupakan penelitian yang terencana, terstruktur dan sistematis mulai dari awal hingga hasil akhir model penelitiannya. Menurut Sugiyono (2014), metode penelitian kuantitatif memiliki arti penelitian yang memiliki landasan filsafat positivisme, sering digunakan dalam penelitian-penilian yang mempunyai populasi atau sampel yang teknik pemilihan sampelnya dilakukan secara random.

\section{Populasi dan Sampel Penelitian}

Bank BUMN di BEl periode 2017 - 2019 sebanyak 4 perusahaan yang menjadi sampel penelitian ini. Industri sektor keuangan masih menjadi saham yang paling dicari dengan nilai kapitalisasi perusahaan tertinggi dan menjadi daya tarik tersendiri bagi para investor saham di pasar modal. Kinerja perusahaan Bank BUMN yang berpengalaman selama puluhan tahun dalam industri jasa keuangan adalah salah satu unsur yang dapat mempengaruhi naik turunnya harga saham perusahaan itu sendiri. Atas dasar itu, penulis memilih Bank BUMN menjadi sampel penelitian dengan teknik pemilihan sampel random dengan kriteria atau purposive sampling.

Pemilihan sampel menggunakan 2 kriteria sebagai berikut:

1. Bank BUMN yang terdaftar di BEI tahun 2017-2019

2. Bank BUMN yang sudah menyampaikan laporan keuangan tahunan periode 2017-2019 di BEI

Berdasarkan kriteria tersebut di atas, maka sampel pada penelitian ini adalah BBNI (PT Bank Negara Indonesia (Persero) Tbk), BBRI (PT Bank Rakyat Indonesia (Persero) Tbk), BBTN (PT Bank Tabungan Negara (Persero) Tbk) dan BMRI (PT Bank Mandiri (Persero) Tbk).

\section{Data, Sumber Data dan Teknik Pengumpulan Data}

Data penelitian berbentuk data panel yang termasuk dalam data sekunder atau data yang didapatkan secara tidak langsung baik dari suatu objek maupun subjek penelitian. Data panel sendiri dapat diartikan sebagai gabungan antara data time series (runtut waktu) dan cross section (data silang). Sumber data diperoleh penulis dengan mengunduh melalui situs web BEI yaitu www.idx.co.id, berbentuk laporan keuangan dan daftar harga saham 
perusahaan. Pengumpulan data dilakukan dengan metode penelitian arsip (archival research), yaitu pengumpulan data berupa laporan keuangan historis yang telah disusun baik dan dipublikasikan.

\section{Teknik Analisis Data}

Teknik analisis data diolah menggunakan Eviews 9 dalam rangka pengujian asumsi klasik dan uji hipotesis. Uji asumsi klasik yang digunakan adalah uji multikolinieritas serta uji heterokedastisitas untuk menguji apakah terdapat pelanggaran terkait asumsi klasik. Sedangkan uji hipotesis terdiri atas uji t (parsial) untuk menguji pengaruh antara satu variabel bebas dengan satu variabel terikat serta uji $f$ (simultan) untuk menguji pengaruh antara seluruh variabel bebas dengan variabel terikat.

\section{H. HASIL DAN PEMBAHASAN}

Hasil pengumpulan data penelitian atas EPS, ROE dan Harga Saham Bank BUMN periode $2017-2019$ yang disajikan pada tabel berikut.

Tabel 1.1

EPS, ROE dan Harga Saham Bank BUMN periode 2017-2019

\begin{tabular}{|l|c|c|c|c|}
\hline Emiten & Tahun & \multicolumn{1}{c|}{ EPS } & \multicolumn{1}{c|}{ ROE } & Harga Saham \\
\hline BBNI & 2017 & 730,00 & 13,65 & $9.123,76$ \\
\hline BBNI & 2018 & 805,00 & 13,67 & $8.341,72$ \\
\hline BBNI & 2019 & 825,00 & 12,41 & $7.619,54$ \\
\hline BBRI & 2017 & 237,22 & 17,36 & $3.282,75$ \\
\hline BBRI & 2018 & 264,66 & 17,50 & $3.401,65$ \\
\hline BBRI & 2019 & 281,31 & 16,48 & $4.234,80$ \\
\hline BBTN & 2017 & 286,00 & 13,98 & $3.432,31$ \\
\hline BBTN & 2018 & 265,00 & 11,78 & $2.480,05$ \\
\hline BBTN & 2019 & 20,00 & 0,88 & $2.115,57$ \\
\hline BMRI & 2017 & 442,28 & 12,61 & $7.009,78$ \\
\hline BMRI & 2018 & 536,04 & 13,98 & $6.800,53$ \\
\hline BMRI & 2019 & 588,90 & 13,61 & $7.306,03$ \\
\hline
\end{tabular}

Berdasarkan tabel 1.1 di atas, dapat diketahui EPS memiliki kecenderungan naik dari tahun 2017 sampai dengan tahun 2019, kecuali untuk BBTN pada tahun 2019 mengalami penurunan secara signifikan dikarenakan adanya tambahan beban pencadangan kredit yang meningkat pada tahun tersebut. EPS tertinggi dari tahun ke tahun bertahan dimiliki oleh BBNI, namun posisi dibawahnya silih berganti dari tiga periode tersebut. 
Dari tabel tersebut juga dapat dianalisa terkait dengan ROE yang nilainya fluktuatif dari tahun ke tahun seiring dengan bertambahnya ekuitas Bank setiap tahun dari hasil perolehan laba. Tidak seperti EPS, nilai ROE tertinggi setiap tahunnya berubah dan masing-masing Bank saling mengejar untuk membuktikan kemampuannya menghasilkan laba untuk para investor saham.

Data harga saham di atas menggunakan harga penutupan saham di BEI. Seperti halnya EPS, harga saham tertinggi dipegang oleh BBNI, meskipun harga sahamnya sendiri berfluktuasi namun BBNI bertahan dengan harga tertinggi setiap tahunnya.

Tabel 1.2

Uji Multikolinearitas

\author{
Variance Inflation Factors \\ Date: $12 / 06 / 20$ Time: 00:57 \\ Sample: 112 \\ Included observations: 12
}

\begin{tabular}{cccc}
\hline \hline Variable & $\begin{array}{c}\text { Coefficient } \\
\text { Variance }\end{array}$ & $\begin{array}{c}\text { Uncentered } \\
\text { VIF }\end{array}$ & $\begin{array}{c}\text { Centered } \\
\text { VIF }\end{array}$ \\
\hline \hline C & 961504.5 & 12.13516 & NA \\
EPS & 1.418054 & 4.547668 & 1.080903 \\
ROE & 5059.563 & 12.13678 & 1.080903 \\
\hline \hline
\end{tabular}

Sumber: Data diolah penulis menggunakan Eviews 9

Berdasarkan hasil pengujian multikolinearitas di atas, dapat dilihat nilai centered VIF untuk variabel EPS serta ROE keduanya bernilai dibawah 10 dan diatas 0,1 sehingga dapat diambil kesimpulan: asumsi klasik terpenuhi dan tidak terjadi multikolinearitas pada penelitian ini. 
Tabel 1.3

Uji Heterokedastisitas

Heteroskedasticity Test Glejser

\begin{tabular}{llll}
\hline \hline F-statistic & 1.125383 & Prob. F(2, $)$ & 0.3662 \\
Obs'R-squared & 2.400654 & Prob. Chi-Square(2) & 0.3011 \\
Scaled explained Ss & 1.619712 & Prob. Chi-Square(2) & 0.4440 \\
\hline
\end{tabular}

Test Equation:

Dependent Variable: ARESID

Method: Least Squares

Date: 12/06/20 Time: 01:02

Sample: 112

Included observations: 12

\begin{tabular}{|c|c|c|c|c|}
\hline Variable & Coefficient & Sto. Error & AStatistic & Prob. \\
\hline $\mathrm{C}$ & 557.6227 & 501.4297 & 1.112066 & 0.2049 \\
\hline EPS & 0.908054 & 0.60649 & $\begin{array}{r}1.492660 \\
0.52200\end{array}$ & 0.1697 \\
\hline & & & & \\
\hline R-squared & 0.200054 & \multirow{3}{*}{\multicolumn{2}{|c|}{$\begin{array}{l}\text { Mean dependent var } \\
\text { S.D. dependent var } \\
\text { Akaike info criterion }\end{array}$}} & 692.8122 \\
\hline Adjusted R-squared & 0.022289 & & & 504.2609 \\
\hline SE. of regression & 498.6294 & & & 15.47392 \\
\hline Sum squared resid & 2237681 & \multirow{3}{*}{\multicolumn{2}{|c|}{$\begin{array}{l}\text { Schwarz criterion } \\
\text { Hannan-Quinn criter. } \\
\text { Durbin-Watson stat }\end{array}$}} & 15.59515 \\
\hline Log likel hood & -89.84353 & & & 15.42004 \\
\hline F-statistic & 1.125383 & & & 2.875889 \\
\hline Prob(F-statistic) & 0.368245 & & & \\
\hline
\end{tabular}

Sumber: Data diolah penulis menggunakan Eviews 9

Berdasarkan hasil pengujian heterokedastisitas di atas, dapat dilihat bahwa nilai probabilitas untuk variabel EPS dan ROE keduanya diatas 0,05 serta dapat diambil kesimpulan bahwa asumsi klasik terpenuhi dan tidak terdapat heterokedastisitas pada penelitian ini. 


\section{Pengujian Hipotesis}

Tabel 1.5

Hasil Regresi Berganda

\begin{tabular}{|c|c|c|c|c|}
\hline \multicolumn{5}{|c|}{$\begin{array}{l}\text { Date: } 12 / 06 / 20 \text { Time: } 01: 05 \\
\text { Sample: } 1 / 2 \\
\text { Included observations: } 12\end{array}$} \\
\hline Variable & Coefficient: & Std. Error & t-Statistic & Prob. \\
\hline $\begin{array}{l}\mathrm{C} \\
\mathrm{EPS} \\
\mathrm{ROE}\end{array}$ & $\begin{array}{r}1786.685 \\
9.237827 \\
-32.17590\end{array}$ & $\begin{array}{l}980.5634 \\
1.190821 \\
71.13060\end{array}$ & $\begin{array}{r}1.822100 \\
7.757529 \\
-0.452360\end{array}$ & $\begin{array}{l}0.1018 \\
0.0000 \\
0.6817\end{array}$ \\
\hline $\begin{array}{l}\text { R-squared } \\
\text { Adiusted R-squared }\end{array}$ & $\begin{array}{l}0.975935 \\
0.947632\end{array}$ & \multicolumn{2}{|c|}{$\begin{array}{l}\text { Mean dependent var } \\
\text { S.D. dependent var }\end{array}$} & $\begin{array}{l}5429.041 \\
2498.025\end{array}$ \\
\hline $\begin{array}{l}\text { S.E. of regression } \\
\text { Sum squared resid } \\
\text { Log Ikelihood }\end{array}$ & $\begin{array}{r}975.0872 \\
8657160 \\
-97.89149\end{array}$ & \multicolumn{2}{|c|}{$\begin{array}{l}\text { Akaike info criterion } \\
\text { Schwarz criterion } \\
\text { Hannan-Quinn criter. }\end{array}$} & $\begin{array}{l}16.81525 \\
16.93848 \\
16.77037\end{array}$ \\
\hline $\begin{array}{l}\text { F-statistic } \\
\text { Prob(F-statistic) }\end{array}$ & $\begin{array}{l}31.59894 \\
0.000085\end{array}$ & \multicolumn{2}{|c|}{ Durbin-Watson stat } & 1.397613 \\
\hline
\end{tabular}

Sumber: Data diolah penulis menggunakan Eviews 9

Hasil analisis regresi berganda di atas dapat dijelaskan sebagai berikut:

1. Hipotesis $1\left(\mathrm{H}_{1}\right)$ yaitu pengaruh EPS terhadap harga saham secara parsial, hasil analisis regresi berganda antara EPS dengan harga saham menunjukkan nilai probabilitas positif kurang dari 0,05 yaitu sebesar $0,0000 \quad(0,000<\alpha=0,05)$. Probabilitas yang lebih rendah dari 0,05 menandakan diterimanya $\mathrm{H}_{1}$ yang berarti EPS dengan harga saham terbukti memiliki pengaruh signifikan, dimana jika EPS mengalami kenaikan maka harga saham juga akan naik dan begitu pun sebaliknya, jika EPS turun maka harga saham akan ikut menurun.

2. Hipotesis $2\left(\mathrm{H}_{2}\right)$ yaitu pengaruh $\mathrm{ROE}$ terhadap harga saham secara parsial, hasil analisis regresi berganda antara ROE dengan harga saham menunjukkan nilai probabilitas positif lebih dari 0,05 yaitu sebesar $0,6617 \quad(0,6617>\alpha=0,05)$. Probabilitas yang lebih tinggi dari 0,05 menandakan tertolaknya $\mathrm{H}_{2}$ yang berarti lemahnya pengaruh ROE terhadap harga saham. Berdasarkan hasil dari penelitian ini, analisa harga saham menggunakan ROE menghasilkan prediksi keuangan yang kurang akurat karena lemahnya pengaruh antara ROE dengan harga saham. Investor saham yang menggunakan rasio ROE sebagai salah satu pertimbangan sebelum membeli saham perusahaan tidak disarankan menggunakan rasio ini secara parsial.

3. Secara simultan, menunjukkan hasil yang berbeda, analisis regresi berganda antara EPS dan ROE dengan harga saham menunjukkan probabilitas F-hitung sebesar 
0,000085 dimana lebih kecil dari 0,05. Kesimpulan dari hal tersebut adalah EPS serta ROE secara bersama-sama memiliki pengaruh terhadap harga saham. Dimana investor bisa memakai kedua rasio ini secara bersamaan untuk menentukan prediksi harga saham sebuah perusahaan, terutama Bank BUMN sebagaimana telah dibuktikan dalam penelitian ini.

4. Hasil pengujian determinasi $R$-Squared dipakai untuk melihat signifikansi pengaruh yang dimiliki variabel bebas terhadap variabel terikat. Dalam penelitian ini, koefisien determinasi yang dihasilkan dari nilai $R$-Squared adalah 0,875335 . Hal tersebut dapat disimpulkan bahwa variabel bebas telah memperjelas pengaruhnya terhadap variabel terikat sebanyak $87 \%$ sedangkan selisihnya merupakan variabel lainnya yang tidak disampaikan dalam penelitian ini.

\section{KESIMPULAN}

Berdasarkan analisa dan pengujian yang telah dilakukan oleh peneliti, berikut kesimpulan yang dapat diambil:

1. EPS berpengaruh positif signifikan terhadap harga saham yang berarti apabila laba per saham perusahaan naik maka pada saat tersebut pula harga jual saham mengalami kenaikan, begitupun sebaliknya apabila laba per saham turun maka harga jual saham pun akan ikut anjlok atau menurunan.

2. ROE tidak memiliki pengaruh signifikan terhadap harga saham, yang dapat diartikan naik turunnya ROE tidak mempengaruhi kenaikan atau penurunan harga jual saham pada pasar modal.

3. EPS dan ROE secara simultan berpengaruh positif signifikan, artinya kenaikan dan penurunan harga saham di pasar modal dipengaruhi oleh kedua variabel secara bersama-sama.

\section{DAFTAR PUSTAKA}

Amalya, N. T. (2018). Pengaruh return on asset, return on equity, net profit margin dan debt to equity ratio terhadap harga saham. Jurnal SEKURITAS (Saham, Ekonomi, Keuangan dan Investasi), 1(3)."

Hakim, L., Sunardi, N. (2017). Determinant of leverage and it's implication on company value of real estate and property sector listing in IDX period of 2011-2015. Man in India, 97(24), pp. 131-148.

Husain, T., \& Sunardi, N. (2020). Firm's Value Prediction Based on Profitability Ratios and Dividend Policy. Finance \& Economics Review, 2(2), 13-26.

Indonesia (1995). Undang-Undang No. 8 Tahun 1995 Tentang Pasar Modal. Jakarta: Menteri Keuangan."

Indriani, D. (2018). Pengaruh Earning Per Share (EPS) Dan Return On Equity (ROE) Terhadap Harga Saham PT Bank Central Asia, Tbk tahun 2011-2015."

Kadim, A., Sunardi, N \& Husain, T. (2020). The modeling firm's value based on financial ratios, intellectual capital and dividend policy.Accounting, 6(5), 859-870.

Lukito, C. P., \& Setiawan, P. (2020). Pengaruh Earning Per Share dan Return On Asset terhadap Harga Saham pada PT. Sepatu Bata Indonesia Tbk. Jurnal IImu Komputer Dan Bisnis, 11(2a), 63-71." 
Nardi Sunardi Et Al (2020). Determinants of Debt Policy and Company's Performance, International Journal of Economics and Business Administration Volume VIII Issue 4, 204-213

Nur'aidawati, Siti. (2018). Pengaruh Current Ratio (CR), Total Asset Turnover (TATO), Debt to Equity Ratio (DER) dan Renturn on Asset (ROA) Terhadap Harga Saham dan Dampaknya pada Nilai Perusahaan. Jurnal Sekuritas Vol. 1, No. 3, 70-83."

Oktavian, Reza. (2019). Pengaruh Earning per Share (EPS) dan Dividend per Share (DPS) Terhadap Harga Saham PT Wijaya Karya (Persero) Tbk. Jurnal Sekuritas Vol. 2, No. 2, 156-171."

Prihadi, Toto. (2012). Analisis Laporan Keuangan Lanjutan Proyeksi dan Valuasi. Jakarta: PPM."

Rusnaeni, N. (2017). Pengaruh Earning per Share (EPS) dan Dividend per Share (DPS) Terhadap Harga Saham pada PT Adhi Karya (Persero) Tbk dan PT Total Bangun Persada Tbk. Jurnal Sekuritas Vol. 1, No. 2, 1-17."

Ruum, N. (2017). Pengaruh Earning per Share (EPS) dan Retrun on Assets (ROA) Terhadap Harga Saham pada PT Indofood Tbk."

Sjahrial, Dermawan. (2012). Pengantar Manajemen Keuangan. Jakarta: Mitra Wacana Media."

Sugiyono. (2014). Metode Penelitian Pendidikan Pendekatan Kuantitatif, Kualitatif dan R\&D. Bandung: Alfabeta."

Sunardi, N. (2019). Profitabilitas, Likuiditas, Dan Multiplier Equity Pengaruhnya Terhadap Harga Serta Return Saham Pada Industri Manufaktur Tahun 2012-2017. Inovasi, 6(1), 58-73.

Sunardi, N., \& Lesmana, R. (2020). Konsep Icepower (Wiramadu) sebagai Solusi Wirausaha menuju Desa Sejahtra Mandiri (DMS) pada Masa Pandemi Covid-19. JIMF (Jurnal IImiah Manajemen Forkamma), 4(1).

Sunardi, N., \& Permana, R. D. I. (2019). Faktor-Faktor Yang Mempengaruhi Harga Saham Dan Dampaknya Pada Nilai Perusahaan (Studi Kasus pada Perusahaan Sub Sektor Pertambangan Minyak dan Gas Bumi yang Terdaftar di Bursa Efek Indonesia Tahun 2013-2017). JIMF (Jurnal IImiah Manajemen Forkamma), 2(2).

Sunariyah. (2011). Pengantar Pengetahuan Pasar Modal. Edisi Keenam. Yogyakarta: UPP STIM YKPN." 